\title{
A Lesson Study as a Development Model of Professional Teachers
}

\author{
Tjipto Subadi ${ }^{1, *}$, Rita Pramujiyanti Khotimah ${ }^{2} \&$ Sri Sutarni $^{2}$ \\ ${ }^{1}$ Geographical Education, Muhammadiyah University of Surakarta, Pabelan Surakarta, \\ Indonesia \\ ${ }^{2}$ Mathematics Education, Muhammadiyah University of Surakarta, Pabelan Surakarta \\ Indonesia \\ *Corresponding author: Geographical Education, Muhammadiyah University of Surakarta, \\ Jl. A. Yani Tromol Pos 1 Pabelan Surakarta, Indonesia \\ Tel: 62-816-652-241Ｅ-mail: tjiptosubadi@yahoo.com
}

Received: April 9, $2013 \quad$ Accepted: May 17, 2013 Published: June 9, 2013

doi:10.5296/ije.v5i2.3831ＵRL: http://dx.doi.org/10.5296/ije.v5i2.3831

\begin{abstract}
The study aims to 1) identify the teachers' problem to develop a development model of professional teachers with a lesson study-based approach at Muhammadiyah Schools of Sukoharjo regency, 2) find an effective lesson study model as a development model of professional teachers, and 3) analyze a lesson study validation as a development model of professional teachers. The research used a phenomenology descriptive-qualitative method. The subjects included the students, teachers, principals, department head of education, and members of the Regional House of Representatives. The techniques of the data gathering employed the observation, documentation, and in-depth interview. The technique of the data analysis applied the first order understanding and second order understanding. It could be concluded that the four problems to improve the teachers' professionalism with a lesson study-based model are as follows: 1) internal, 2) external (teachers' commitment and concern), 3) an effective lesson study model based on a plan-do-see circle, collaboration, and collegial tutor, and 4) a lesson study validation in relation with the validations of open lesson and reflection, theory, and implementation.
\end{abstract}

Keywords: model; improvement; professionalism; teacher; lesson study; validation 


\section{Introduction}

An effort of improving educators' qualification takes such factors as teachers' intention, students, methods, strategy, media, facilities, library, laboratory, surrounding and management, and development models. The improvement in teacher's learning quality with collaborative model at every education level will take an impact on learning quality. So, it is expected that it will improve students' academic achievement and ultimately result in the improvement in the Indonesian education quality where this quality is lower than other countries' one.

According to Subadi (2009: 19), of the 146,052 Primary Schools in Indonesia, there are only 8 schools to be accepted as a world level in the Primary Years Program (PYP). Of the 20,918 Junior High Schools and 8,036 Senior High Schools, there are only 8 and 7 schools to be accepted as a world level in the Middle Years Program (MYP) and the Diploma Program (DP), respectively. In reference to the data of the 2002-2003 teachers qualification, the reasonable teachers for the students of Primary Schools, Junior High Schools, Senior High Schools, and Vocational Schools amounted to 21,07\% (state teachers) and $28,94 \%$ (private teachers), 54,12\% (state teachers) and 60,09\% (private teachers), 65,29\% (state teachers) and 64,73\% (private teachers), and 55,49\% (state teachers) and $58,26 \%$ (private teachers), respectively.

The low educational quality indicates that there are problems in Indonesian educational system, including educational paradigm as a basis of whole educational system, development model of teachers and learning strategy, and practical aspects of education such as cost, facilities, and teachers' welfare. In response to the low quality, the government passes the Act of the Republic of Indonesia No. 14/2005 about Teachers and Lecturers. The Act stipulates an implementation of educational system and development of teachers and lecturers in order to be professional. A teacher or lecturer to be professional must meet academic qualifications, have an educational certificate, and be competent; and consequently he or she will get a high reward.

Apart from the Act, as a development model of teachers the lesson study in Japan can also be useful as a model in Indonesia. In this study, the lesson study is a development model of teachers as a process of teachers training in circle and continuity beginning with teachers in collaboration with other teachers for plan, action, and reflection.

An improvement in professional educators means an improvement in teachers learning quality. It is a step for making a better learning as expected in normative criteria, i.e., a result of better action than previous learning. In the study, an improvement is related to that in learning quality that takes a positive influence on students' academic achievement. This learning is substantially an interactive process between students and their environment that produces a change in a better attitude (Mulyasa, 2002: 100).

According to Harta (2009: 9-14), an effort of improving a teacher's professionalism in a learning process he or she plays a role as a learning source, facilitator, organizer, demonstrator, counselor, motivator, and evaluator. To be a professional teacher is 
necessary to insensitively develop a 'development model of teachers' ('lesson study') as successfully developed in Japan.

Lesson study was developed in 1870s (Inagaki and Sato, 2012: 3). It is a case analysis model of learning activity aimed to help develop teachers' professionalism and provide them a chance of mutual learning on the basis of real activities in the class. In Japan, as a development model of teachers the lesson study can improve teachers' professionalism and educational quality. For the Japan teachers, it is used as a development of educators in continuity where teachers analyze a learning plan, activity, observation, and reflection collaboratively. The model motivates students to take an active and collaborative learning while teachers try to make students 'get accustomed to learning'.

In the lesson study, teachers can choose and implement a variety of learning models and strategies in conformity with situation, condition, and problem. The learning models can be contextual, quantum, integrated, problem-based, and cooperative. The lesson study-based learning strategies classified into cooperative learning model are a) Student Teams Achievement Division (STAD), b) Cooperative Integrated Reading and Composition (CIRC), c) Jigsaw, d) Learning Together, e) Group Investigation, and f) Cooperative Scripting (Lie, 2004: 27).

In the study, the problems are as follows: 1) what is a problem with an improvement in lesson study-based learning quality as a development model of teachers at Muhammadiyah Senior High Schools of Sukoharjo regency?; 2) what is an effective lesson study model as a development model of professional teachers?; and 3) what is the validation of lesson study as a development model of professional teachers in a limited scope?

The aims of the study are as follows: a) describing a problem with an improvement in lesson study-based learning quality as a development model of teachers at Muhammadiyah Senior High Schools of Sukoharjo regency; b) finding an effective lesson study model as a development model of professional teachers; and c) describing the validation of lesson study as a development model of professional teachers in a limited scope.

\section{Research Method}

The research used a phenomenology descriptive-qualitative method with a socially-defined paradigm in micro analysis. The paradigm will provide individuals as a research subject that interprets questions in the study.

The research design used a class research action based-lesson study model. The lesson study circle employed a class action research modified with Subadi's model (2009) as described in Figure 1.

The study was located at Muhammadiyah Schools of Sukoharjo regency. The informants included the students, teachers, principals, Department Heads of Education, members of the House of Representatives, and lecturers.

The techniques of data gathering were observation and in-depth interview. The observation 


\section{Macrothink}

International Journal of Education

ISSN 1948-5476 2013, Vol. 5, No. 2

technique was employed to examine the activities in the classes. The researchers interviewed the teachers, principals, supervisors of education, members of the House of Representatives, and lecturers to find the teachers' problems at Muhammadiyah Schools of Sukoharjo regency in improving a lesson study-based learning quality, and describing an effective lesson study and its validation as a development model of professional teachers.

A process of interview used the first order understanding and second order understanding where the researchers provided a chance of the individuals as a research subject to interpret the questions asked by the researchers. Then, the researchers understood their interpretations for finding their accurate meaning, but the researchers' understanding may not be opposite to the first interpretation (Berger, 1967: 56). The technique of data analysis applied an interactive model, including data reduction, data display, and conclusion/verification (Miles and Huberman, 2007:15-21). 


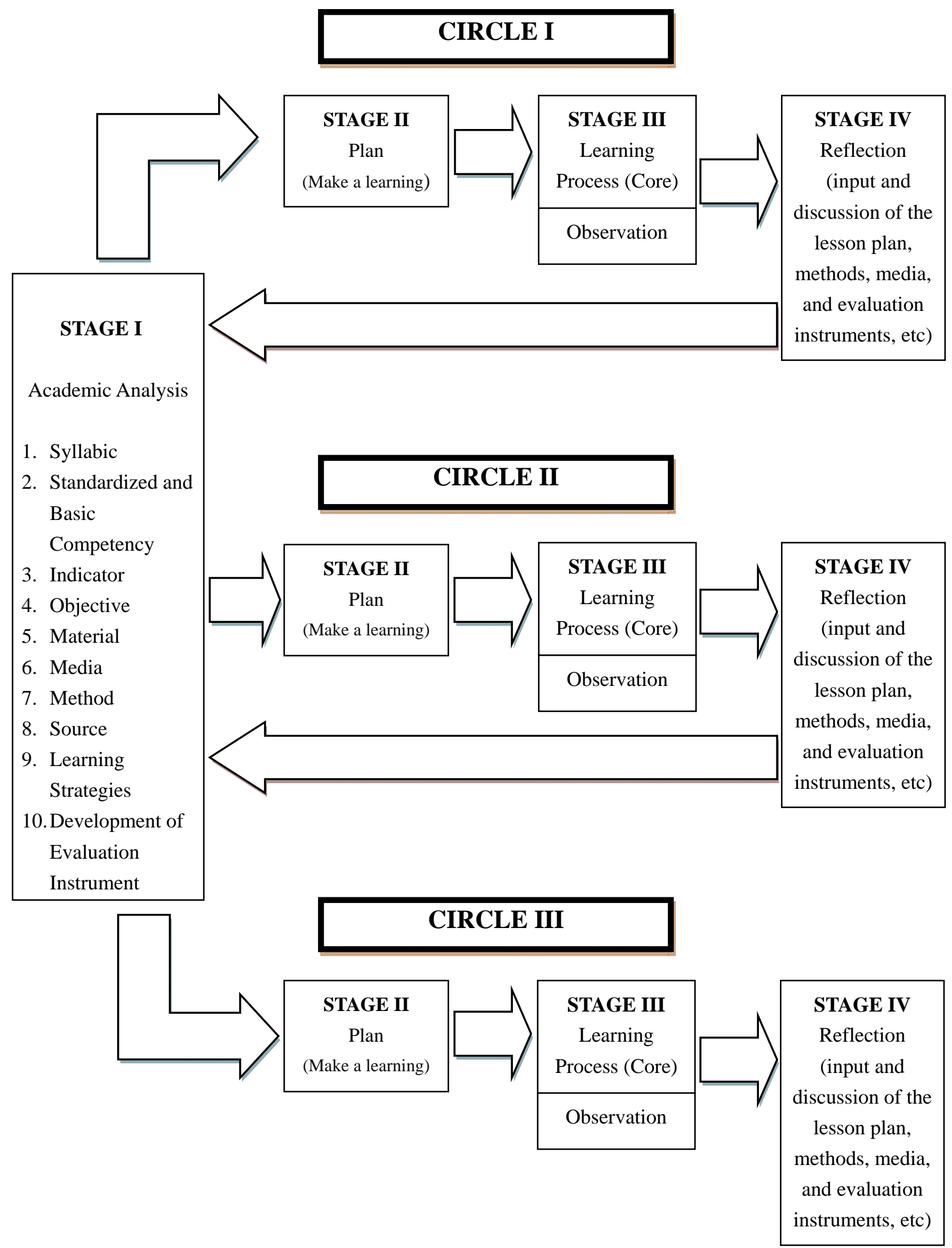

Figure 1: Modification Class Research Action- Based Lesson (Subadi’s Model, 2009) 


\section{Research Findings and Discussion}

The research findings of the internal problems with improvement in a lesson study-based learning quality as a development model of teachers at Muhammadiyah Schools of Sukoharjo regency are as follows: first, in relation with their internal capacities, the teachers were difficult to develop a curriculum into a quality learning-based curriculum, scientific concepts and innovative learning steps, and lesson study as a model of improving a learning quality.

Second, the external problems resulted from the students, principals, supervisors of education, surroundings, curricula, and facilities. The students were difficult to make an interaction with other students and teachers. They were incompetent and incapable to understand instructional materials and unskillful at operating media. The principals and supervisors were low in monitoring. The natural surroundings did not provide learning activities. The curriculum was not equally socialized. The facilities of the schools for learning activities were limited.

Third, the problems with the teachers' commitments are as follows: many teachers were not developing their competencies. They were not getting accustomed to reading and developing instructional materials, and implementing the learning trainings in the classes. It is opposite to Sukirman's idea, stating the key to the successful lesson study is that the teachers implement the trainings in the classes.

Fourth, the problems with the teachers' concern are as follows: many teachers taking part in learning training were merely due to a duty of the principals. They were unmotivated to develop their competencies. If the teachers did not take any training, it would mean that there was not a great concern for coming into being from the teachers themselves. So, if the government provides some training to teachers, the training will not be meaningful. Concerning some lesson study training, likewise, if the teachers are unmotivated to take part in the training, it will be useless.

An effective lesson study as a development model of professional teachers is Course Teacher Association, school, peer-collaborative, and tutorial learning-based. It must be implemented in circle, stage, including planning, doing (action and observation), and seeing (reflection and evaluation).

A lesson study process in the study begins with the teachers in collaboration (discussing a learning problem), makes a lesson plan, teaches and learns in reference to the lesson plan, invites colleagues for observation, and makes a reflection of the learning. As a development model of professional teachers at Muhammadiyah Schools of Sukoharjo regency, a lesson study is a circle (plan-do-see) based by two mathematics teachers of SMA Muhammadiyah Kartasura Senior High School (Figure 2) and SMK Muhammadiyah 1 Kecamatan Kota Sukoharjo Vocational School (Figure 3), a model named Anggit Wibowo and Wiwit Waryani, respectively. 


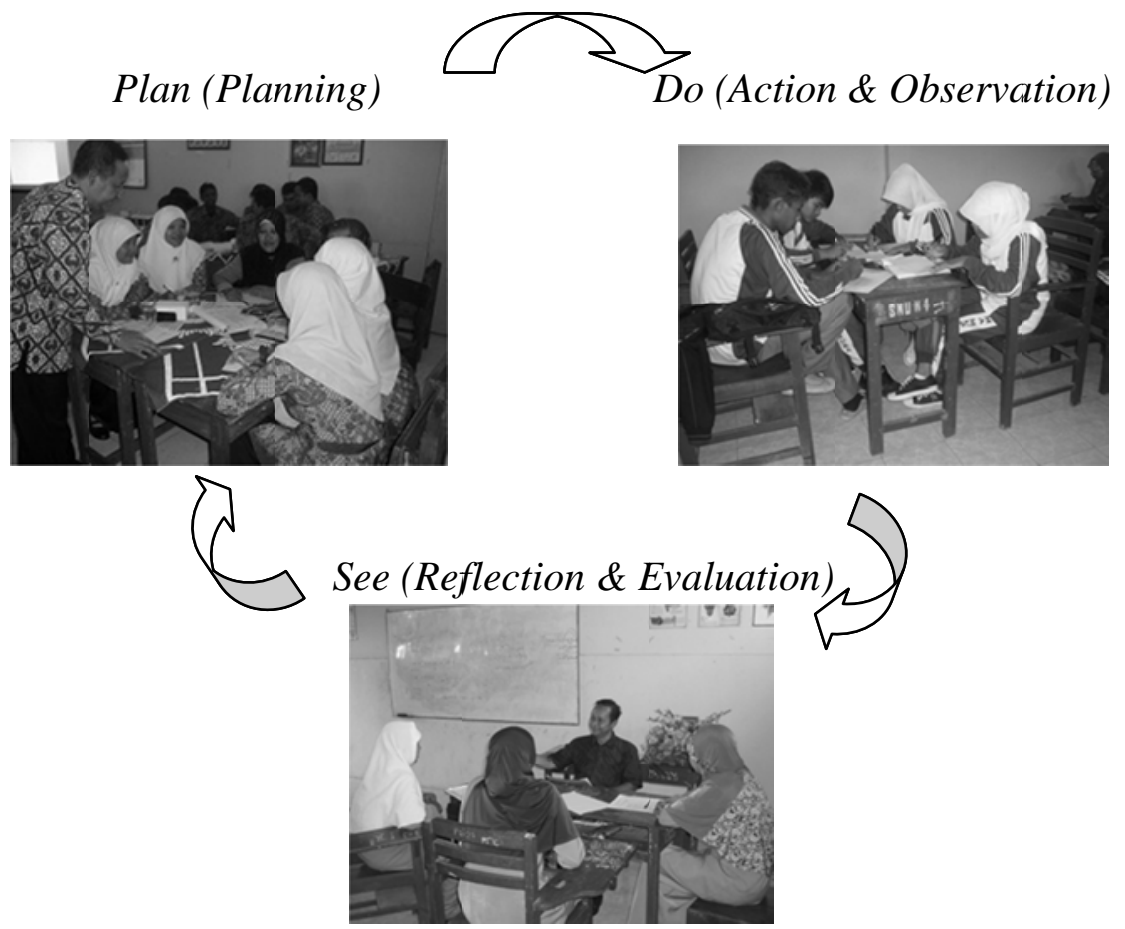

Figure 2: Cycle Lesson Study in High School of Muhammadiyah Kartasura

(Observation Documentation, 2012)

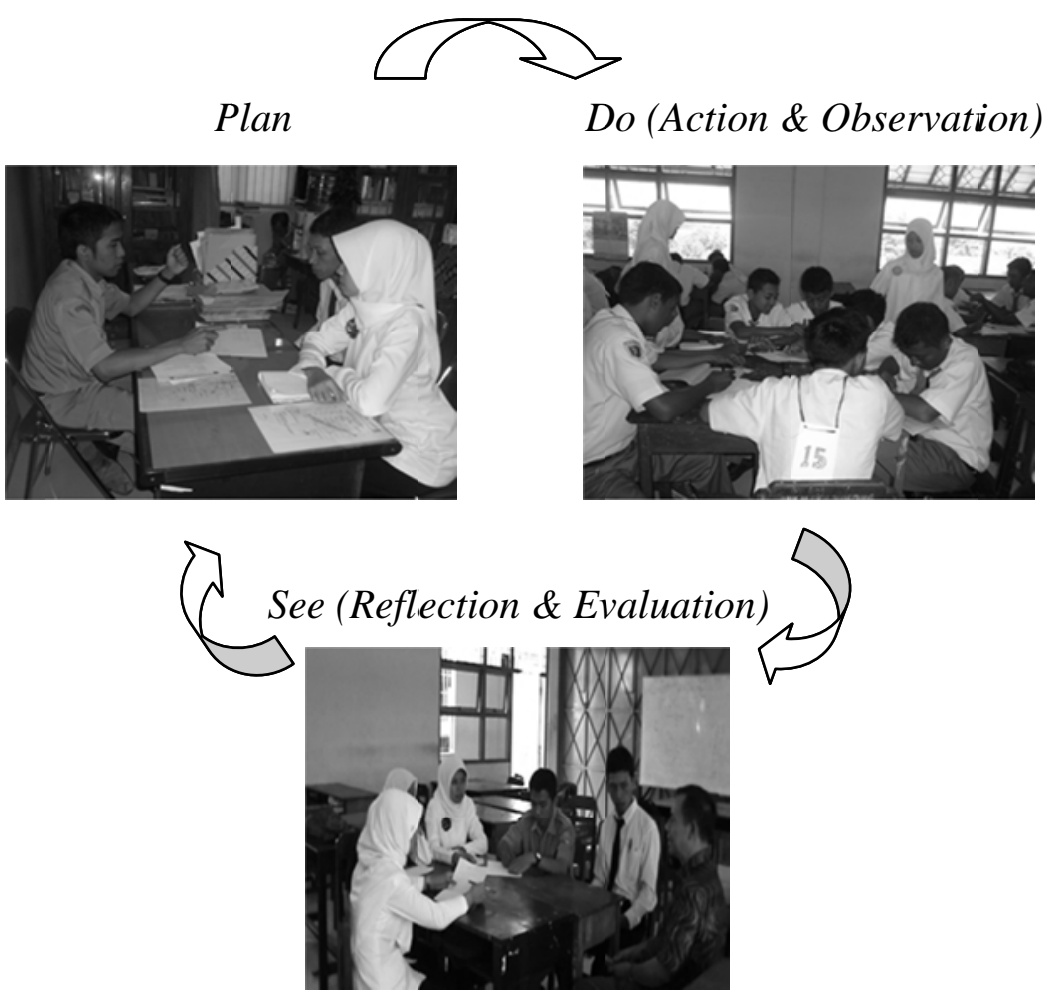

Figure 3: Lesson Study Cycle Vocational School of Muhammadiyah 1 Sukoharjo (Observation Documentation, 2012) 
Referring to the questionnaires and interview with the students in open lesson, their response to a lesson study-based is that before the lesson study, there was a significant difference from after it (for the students of Senior High Schools at 15\%:55\% ratio and for those of Vocational School students at 20\%:60\% ratio). (See in Figure 4).

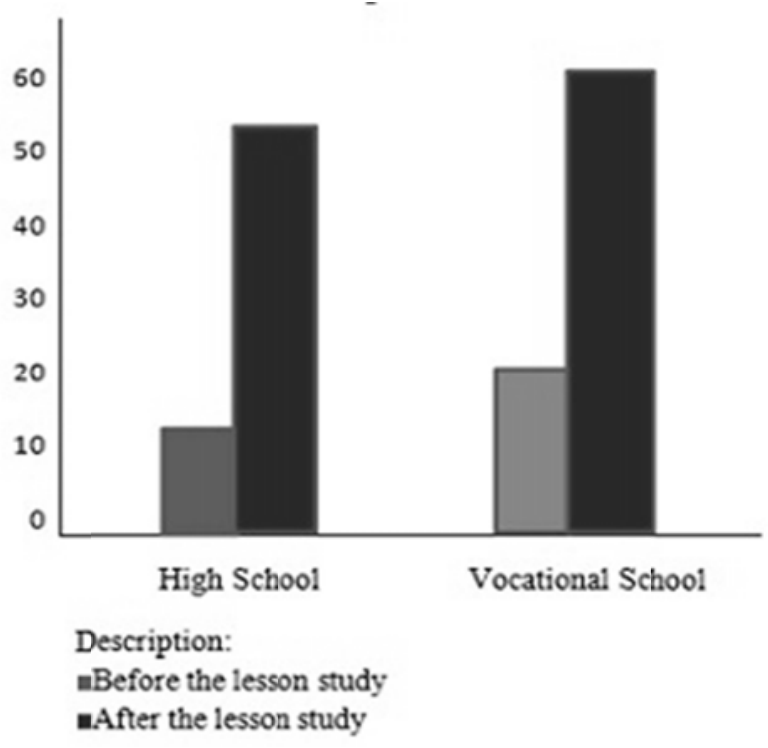

Figure 4: Students Responses Models

According to the teachers, a lesson study model is said to be very positive as a development model of professional teachers. Furthermore, they state that the program can significantly improve teachers' competencies (as seen in Figure 5) with the following indicators: 1) more complete facilities in ready for use, 2) a better skill in the use of information technology, 3) a development learning method and strategy, and 4) a lesson study program in continuity.

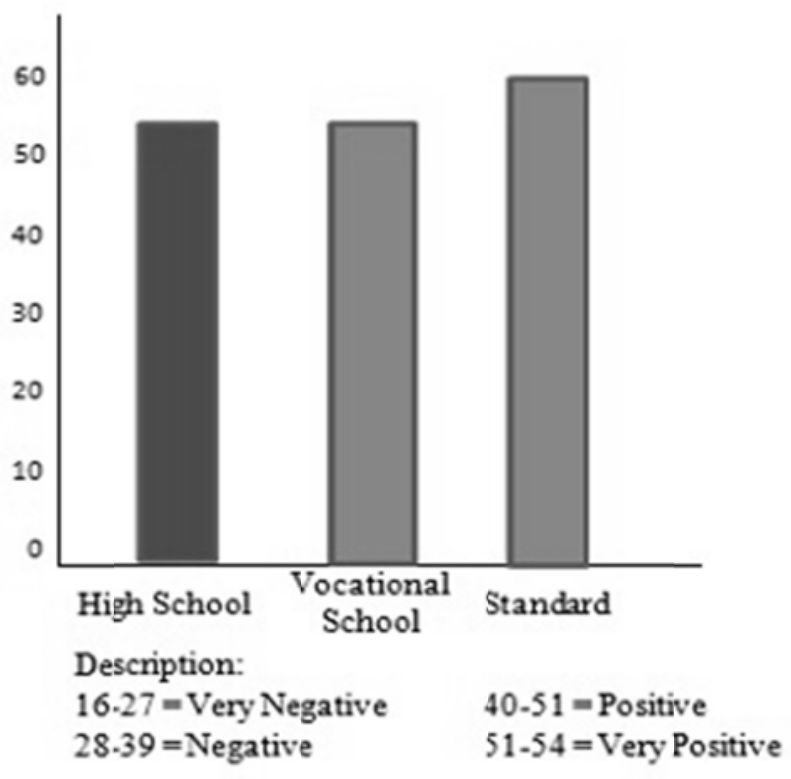

Figure 5: Teacher Statements Models 
Based on the description above, thus, to produce a more effective lesson as a development model, it is suggested that the model must be a Course Teacher Association-based and be in charge of the Team Work of the Principals or Principal Association. The implementation of the program is coordinated by the Team Work of the Teacher. The operating implementation is held by every school coordinated by a model teacher. It is routinely monitored and evaluated and financed by a school. For operating the implementation, furthermore, it is necessary to establish a team work; a principal encourages a model teacher; and it is collaboratively carried out between teachers and others, between teachers and students, between students and others, and collegial tutors.

The effective lesson study takes an impact on: 1) there is the significant difference between before and after the program implemented in both the Senior High School and Vocational School where it positively influences on the teachers achievement. 2) The teachers competency is significantly improved where the indicators are a set of more complete and readier-for-use learning, better skill in Information Technology, developed learning strategy, peer tutor learning, need of lesson study program in continuity. 3) An improvement in the learning qualities includes learning preparation, collaborative-work growth, development of learning strategy, collegiality, students' readiness for learning, reflection-based learning process, development of learning media, and development of assessment instrument.

It is stated that the findings of the lesson study are effective, i.e., 1) before and after the program, there is a significant difference for the students of Senior High Schools at 15\%:55\% ratio and for those of Vocational School students at 20\%:60\% ratio). 2) The program can significantly improve teachers with the following indicators: a) more complete facilities in ready for use, b) a better skill in the use of information technology, c) a development learning method and strategy, and d) a lesson study program in continuity. 3) The model gives a contribution to the learning qualities, including learning preparation, collaborative work growth, development of learning strategy, collegiality, readiness of the students' learning, reflection-based learning process, development of learning media, and development of evaluation instruments.

The lesson study validation as a development model of professional teachers is developing teaching plan and teaching material and operating open lesson and reflection. The three validations are developed into the validations of a lesson study team, schedule operation, consistency and operating continuity, documentation, improvement in learning quality, principals' and students' responses, and consultants.

In addition, a learning development validation of lesson study learning model is conducted by the Teacher Team Work at the Task Force, trial and error (implementation) at every school taken by its teachers. The positive findings of the lesson study implementation are discussed by the Principal Association and Course Teachers).

The lesson study validation needs to be followed up, implemented, and programmed so that it can effectively and optimally be conducted. Therefore, it is necessary to evaluate its effectiveness. As a model of improving teachers' quality in a limited area, the validation is 
conducted in program in every school by a model teacher. Its findings are discussed at the Team Work of the Teachers or the Task Force for reflection and evaluation.

The teachers' responses to the lesson study as a model of improving the teachers' quality are very positive. It needs a facilitator and motivator of the principal and department head, and its implementation must be monitoring in the class.

The decision makers (educational supervisors') responses are supporting and giving a very wide chance to teachers for improving their professionalism through a lesson study-based learning. An improvement of the teachers' professionalism should be implemented in every school and its result is discussed in the Teacher Team Work. It is line with the members of the House of Representative, stating that a development model of teachers is coordinated by the educational commission where it will give a contribution to its model and it is suggested to establish a team work.

A lesson study-based active, innovative, creative and pleasurable learning model as a development model of professional teachers at Muhammadiyah Schools of Sukoharjo regency is a collaborative and cooperative lesson study-based learning model since these collaborative and cooperative models are difficult to differentiate and separate one from another. In addition, an effective lesson study is coordinated by the Principal Association, and it is implemented by every school through the Course Teacher Association.

If there is a problem with operating a lesson study-based learning, it is recommended to hold a routine and continual training, use a training budget in the School Budget, Regional Budget, and National Budget, establish a team work, monitor and evaluate periodically, give a motivation by consultants and officials, monitor periodically by consultants, and make an MoU (Memory of Understanding) with Higher Education with an expert in a lesson study.

The research findings of a problem with the teachers for improving the quality are nearly similar to Chokshi's research (2005) entitled Reaping the Systemic Benefits Lesson Study. Based on the findings, it can be concluded that a learning process needs any motivation and vision. The students and teachers internal problems (i.e., low learning motivation) must immediately be solved for producing a comfortable learning. The external problems, including the schools' limited facilities, are the same as Chokshi's research (2004) entitled Challenges to Importing Japanese Lesson Study. The findings of the research state that a practical learning method could encourage students to understand a lesson easily because it is supported with facilities. Therefore, a problem of facilities must immediately be solved.

In terms of a development model of professional teachers, in his research findings entitled Inquiry in the Life Sciences: The Plant-in-a-Jar as a Catalyst for Learning (2007), Thomson stated that 1) the teachers tried to change a learning process. It means that they must be creative and innovative in a learning activity. 2) The teachers found an alternative of teaching an instructional material with a certain basic competency so that learning becomes increasingly comfortable. 3) The teachers created a learning model as a reference to students. Furthermore, Thompson suggested the importance of developing educators' 
professionalism more creatively and innovatively for producing a comfortable and democratic learning.

As a model of quality improvement, a validation of model development is related to Stewart's research (2005) entitled A Model for Teacher Collaboration. The research findings showed that the best step to produce a positive improvement in every class in a school is adapting a tested (validated) learning model.

A lesson study-based active, innovative, creative, and comfortable learning model is related to Robinson's research (2006), entitled Prospective Teachers' on Microteaching Lesson Study. It could be concluded that the mathematics learning with a microteaching and lesson study-based approach in which teachers collaborated with one another established a theoretical-to-practical learning relation.

Likewise, the research findings of the lesson study are related to William Cerbin and Bryan Kopp' (2006), a lecturer of University of Wisconsin-L Crosse, entitled Lesson Study as a Model for Building Pedagogical Knowledge and Improving Teaching. It could be concluded that with a lesson study model, the teachers could make collaboration for solving a problem to achieve a teaching-learning objective. In his research, Mathematics Teachers Professional Development through Lesson Study in Indonesia, Marsigit (2007) states that the lesson study model gave a chance for the teachers and students to express some ideas.

\section{Conclusion}

It is found that the four problems to improve the teachers' professionalism of Muhammadiyah Schools of Sukoharjo regency are as follows: 1) the teachers' internal problems, 2) the external problems, including the students, principals, supervisors of education, surroundings, curricula, and facilities, 3) the problems with the teachers' commitments, and 4) the problems with the teachers concern. An effective lesson model as a development model of professional teachers is a circle (plan-do-see)-, Course Teacher Association, school, collaboratively, collegial tutor-based coordinated by the Principal Team Work and the Principal Association.

The implementation of the program is coordinated by the Team Work of the Teacher. The operating implementation is held by every school coordinated by a model teacher. It is routinely monitored and evaluated.

It is stated that the findings of the lesson study are effective, i.e., 1) before and after the program, there is a significant difference for the students of Senior High Schools at 15\%:55\% ratio and for those of Vocational School students at 20\%:60\% ratio). 2) The program can significantly improve teachers' quality with the following indicators: a) more complete facilities in ready for use, b) a better skill in the use of information technology, c) a development learning method and strategy, and d) a lesson study program in continuity. 3) The model gives a contribution to the learning qualities, including learning preparation, 
collaborative work growth, development of learning strategy, collegiality, readiness of the students' learning, reflection-based learning process, development of learning media, and development of evaluation instruments. The lesson study validations as a development model of professional teachers are those of developing teaching plan and teaching material and operating open lesson and reflection, theories by experts, implementation by a model teacher and lecturer as a consultant.

It is suggested that the government should make a policy strategy in establishing an educational system for developing a model for improving teachers' quality through a lesson study-based training in continuity, a consultant-based implementation, and lesson study as an alternative of a development model of professional teachers.

\section{Acknowledgement}

We thank to the DP2M that has funded the Strategic Excellent of Muhammadiyah University of Surakarta with an approval letter date 24 February 2012. We also thank to the chairman of the Muhammadiyah Elementary and Secondary Education Section of Sukoharjo regency, principals, and students of Muhammadiyah Junior Higj School, Senior High School, and Vocational School of Sukoharjo regency for the lesson study research.

\section{References}

Berger, P., \& Luckman. T. (1967). The Social Construction of Reality. London: Allen Lane.

Chakhshi, S., \& Fernandes. C. (2004). Cellenger to Importing Japanes Lesson Study. Bloomington Concerns, Miscoseptions, and Nuancen. Retrieved from www.proquets.umi.com

Chakhshi. S. (2005). Reaping the Systemic Benefits of Lesson Study Bloomington: Insights from the U.S. Vol 86. Retrieved from www.proquets.umi.com

Departemen Pendidikan Nasional. (2003). Undang-Undang Republik Indonesi Nomor 20 Tahun 2003 Tentang Sistem Pendidikan Nasional. Jakarta: Depdiknas RI.

Departemen Pendidikan Nasional. (2005). Undang-Undang Republik Indonesia Nomor 14 Tentang Guru dan Dosen. Jakarta: Depdiknas RI.

Harta I., \& Djumadi. (2009). Pendalaman Materi Metode Pembelajaran. Modul PLPG. Departeman Pendidikan Nasional. Universitas Muhammadiyah Surakarta Panitia Sertifikasi Guru Rayon 41. Surakarta: BP FKIP-UMS.

Inagaki, T., \& Sato, M. (2012). Jugyo Kenkyu Nyumon (Introduction to Lesson Study). Tokyo: Iwanami.

Lie A. (2004). Cooperative Learning. Jakarta: Grasindo. 
Marsigit. (2007). Mathematics Teachers' Professional Development Through Lesson Study in Indonesia. Eurasia Journal of Mathematics, Science \& Technology Education, 3(2), 141-144.

Miles, B.M., \& Michael, H. (2007). Qualitative Data Analisys. Jakarta: UI Press.

Mulyasa. (2004). Menjadi Kepala Sekolah Profesional. Bandung: Remaja rosda Karya.

Robinson. (2006). Lesson Study: An example of its adaptation to Israeli middle school teachers. Retrieved from stwww.weizmann.ac.il/G-math/ICMI/Robinsonproposal.doc

Subadi, T. (2010). Sosiologi dan Sosiologi Pendidikan (Suatu Kajian Boro dari Perspektif Sosiologis Fenomenologis. Katasura: Fairuz media Duta Pemata Ilmu.

Subadi, T. (2009). Pengembangan Model Untuk Meningkatkan Kualitas Guru Melalui Pelatihan Lesson Study di Sekolah Dasar Kota Surakarta. Jurnal Sekolah Dasar Kajian Teori dan Praktik Pendidikan. Tahun 18. Nomor 2 November 2009. ISSN 0854-8285. Malang: UN Malang.

Stewart, R., \& Brederfur, J. (2005). Fusing Lesson Study and Aithetic Achievent. Bloomington: A. Model for Teacher Collabooration. Retrieved from www.proquest.umi.com

Tim Pengembang Sertifikasi Kependidikan. (2003). Pedoman Sertifikasi Kompetensi Tenaga Kependidikan. Jakarta: Depdiknas.

Thompson, S. (2007). Science Activities. Washington: Winter 2007, 43(4), 27.

William, C., \& Bryan, K. (2006). Lesson Study as a Model for Building Pedogogical Knowledge and Improving Teaching. International Journal of Teaching and Learning in Higher Education, 18(3), 150-257.

\section{Copyright Disclaimer}

Copyright reserved by the author(s).

This article is an open-access article distributed under the terms and conditions of the Creative Commons Attribution license (http://creativecommons.org/licenses/by/3.0/). 